\title{
Effects of Dicyclohexylamine on the Changes in Spermine Levels in Hiproly Barley Callus after Auxin Withdrawal
}

\author{
Yoshinobu KatoH and Tadao HaSEGAWA* \\ Life Science Division, Hokkaido Institute of Public Health, \\ Sapporo, Hokkaido 060, Japan \\ *Department of Agricultural Chemistry, Tokyo University of Agriculture, \\ Setagaya-ku, Tokyo 156, Japan \\ Received October 24, 1988
}

\begin{abstract}
Changes of the contents and biosynthetic rates of polyamines and enzyme activities involved in polyamine synthesis as affected by dicyclohexylamine (DCHA) were examined in Hiproly barley callus. The incorporation of $\left[1,4-{ }^{14} \mathrm{C}\right]$ putrescine into spermidine increased rapidly after auxin withdrawal, while the incorporation of $\left[1,4-{ }^{14} \mathrm{C}\right]$ putrescine or [diaminobutane $\left.1,4-{ }^{14} \mathrm{C}\right]$ spermidine into spermine increased gently. The addition of DCHA suppressed the incorporation of [3,4$\left.{ }^{14} \mathrm{C}\right]$ methionine or $\left[1,4-{ }^{14} \mathrm{C}\right]$ putrescine into spermidine. In contrast, the incorporation of $[3,4-$ ${ }^{14} \mathrm{C}$ ]methionine or [diaminobutane $1,4-{ }^{14} \mathrm{C}$ ]spermidine into spermine increased in the callus by treatment of DCHA. The contents of spermine in the callus increased about 2 -fold after treatment with $10 \mathrm{mM}$ DCHA. The activity of spermidine synthase in the callus after auxin withdrawal increased rapidly. Inhibition of spermidine synthase by DCHA stimulated spermine synthesis and the activity of spermine synthase was elevated about 10 -fold after treatment with $10 \mathrm{~mm}$ DCHA. However, DCHA had significant effects on the activity of $S$-adenosylmethionine decarboxylase and the levels of $S$ methyladenosylhomocysteamine. $S$-Methyladenosylhomocysteamine contents increased about $\mathbf{2 0}$-fold. The changes in the spermine levels paralleled the changes in the $S$-methyladenosylhomocysteamine contents. These results suggested that in Hiproly barley callus the biosynthesis of spermine were regulated by the levels of aminopropyl donor and that the availability of $S$-methyladenosylhomocysteamine may be rate-limiting for the synthesis of spermine.
\end{abstract}

In higher plants polyamines are involved in important physiological phenomena such as cell division, growth, and senescence. ${ }^{1,2)}$ The mechanism of polyamine functions may be due to interaction with proteins and nucleic acids. ${ }^{3}$

In cultured plant cells and tissues, recent work also indicates a role for polyamines in organ differentiation. For example, elongation growth is correlated with high putrescine, and dividing cells are rich in spermidine and spermine. ${ }^{4)}$ Katoh et $a l^{5)}$ found that when Hiproly barley callus was placed on Murashige and Skoog's medium without 2,4-D, adventitious roots formed in the callus. And they showed that the levels of spermidine and spermine in the callus increased during differentiation. ${ }^{5)}$ Moreover, the addition of spermidine or spermine to the medium without 2,4-D stimulated the root formation on the callus. ${ }^{5}$ )
Organ formation of Hiproly barley callus was correlated with high spermidine and spermine.

Spermidine and spermine are synthesized from putrescine by the addition of succesive aminopropyl moieties derived from $S$-methyladenosylhomocysteamine. ${ }^{6)} S$-Methyladenosylhomocysteamine as aminopropyl donor is a key intermediate in the biosynthesis of spermidine and spermine. Thus, changes in spermidine and spermine biosynthesis may be closely related to the levels of $S$-methyladenosylhomocysteamine or the activities of both polyamine synthases.

In recent work, dicyclohexylamine (DCHA) has been shown to inhibit spermidine accumulation in bacteria, animal, and plant cells. ${ }^{7 \sim 11}$ ) DCHA is a competitive inhibitor of spermidine synthase. Moreover, DCHA inhibits growth in Helianthus tuber explants ${ }^{12}$ and 
carrot embryogenesis. ${ }^{13)}$

The results in the literature cited above indicated that high spermidine or spermine biosynthesis affected the organ formation in cultured plant cells and tissues. We investigated how spermidine and spermine biosynthesis were regulated in the callus after auxin withdrawal, and DCHA was used to regulate the spermidine and spermine biosynthesis on root formation of the callus. This paper describes the effects of DCHA on the levels of spermidine and spermine in Hiproly barley callus after auxin withdrawal.

\section{Materials and Methods}

Materials and chemicals. Hiproly barley (Hordeum disticum L. var. Hiproly) was used in the experiments. Spermidine and spermine were obtained from Aldrich Chemical Co., $S$-adenosylmethionine (SAM) and dicyclohexylamine sulfate (DCHA) from Sigma Chemicals, and 2,4-dichlorophenoxyacetic acid (2,4-D) from the Tokyo Kasei Co. Synthetic $S$-methyladenosylhomocysteamine (dSAM) was a generous gift from Dr. K. Samejima, Fac. Pharm., Johsai Univ., Saitama, Japan. Aquazol-2 and L$\left[{ }^{14} \mathrm{C}\right.$-carboxyl]-S-adenosylmethionine $(59.8 \mathrm{mCi} / \mathrm{mmol})$ were obtained from New England Nuclear, and L-[3,4$\left.{ }^{14} \mathrm{C}\right]$ methionine $(45 \sim 60 \mathrm{mCi} / \mathrm{mmol}), \quad\left[1,4-{ }^{14} \mathrm{C}\right]$ putrescine $(90 \sim 120 \mathrm{mCi} / \mathrm{mmol})$, and [diaminobutane $1,4-^{14} \mathrm{C}$ ] spermidine $(90 \sim 120 \mathrm{mCi} / \mathrm{mmol})$ from Commissariat a $\mathrm{L}^{\prime}$ Energie Atomique. Murashige and Skoog's medium was obtained from Flow Laboratories.

Induction and proliferation of callus from Hiproly barley. Hiproly barley callus was induced and grown on Murashige and Skoog's medium containing $2 \mathrm{mg} / 1$ of 2,4 D. Calli were subcultured every 8 weeks. Calli were kept for at least two passages on Murashige and Skoog's medium containing $2 \mathrm{mg} / \mathrm{l}$ of 2,4-D before experiments, and transferred to Murashige and Skoog's medium containing various concentrations of DCHA. Hiproly barley calli at different stages during cultivation were placed in Erlenmyer flasks. containing a basal medium with L-[3,4$\left.{ }^{14} \mathrm{C}\right]$ methionine $(1 \mu \mathrm{Ci}),\left[1,4{ }^{14} \mathrm{C}\right]$ putrescine $(0.5 \mu \mathrm{Ci})$, or [diaminobutane $1,4-{ }^{14} \mathrm{C}$ ]spermidine $(0.5 \mu \mathrm{Ci})$. After incubation for $24 \mathrm{hr}$, the calli were taken out, rinsed twice with distilled water, and stored at $-20^{\circ} \mathrm{C}$.

Polyamine extractions. Calli (100 mg) were homogenized in $1 \mathrm{ml}$ of chilled $5 \%$ perchloric acid with a glass homogenizer. This homogenate was centrifuged at $20,000 \times g$ for $20 \mathrm{~min}$, and the supernatant containing the free polyamines was stored at $-20^{\circ} \mathrm{C}$.
Benzoylation and high performance liquid chromatographic analysis of polyamines. The polyamine concentration in the extract was measured by a method modified from that of Redmond and Tseng. ${ }^{14)}$ The acid-extracted free polyamine solution $(1.0 \mathrm{ml})$ was mixed with $2 \mathrm{ml}$ of $2 \mathrm{~N}$ sodium hydroxide in a $50-\mathrm{ml}$ glass centrifuge tube to which was added $10 \mu \mathrm{l}$ of benzoyl chloride. The mixture was shaken with a Vortex mixer for $45 \mathrm{sec}$, and left for $20 \mathrm{~min}$. Two ml of saturated sodium chloride solution was added and the solution was extracted with $4 \mathrm{ml}$ diethyl ether. After centrifugation at $1,500 \times g$ for $15 \mathrm{~min}$, two $\mathrm{ml}$ of the upper ether phase was taken out and evaporated under a stream of nitrogen. The residue was dissolved in $100 \mu 1$ of methanol, and $10 \mu \mathrm{l}$ of the solution was used for high performance liquid chromatography (HPLC).

HPLC of benzoylpolyamines was run by a Waters model 510 with an ultraviolet detector on a $8 \mathrm{NVC}_{18}$ column (Radial Pak, Waters Associates) at $254 \mathrm{~nm}$. A linear gradient of acetonitrile from $36.5 \%$ to $100 \%$ in $1 \%$ acetic acid over a period of $20 \mathrm{~min}$ was used as a mobile phase at a flow rate of $3 \mathrm{ml}$ permin.

Labeled polyamines were extracted with $5 \%$ perchloric acid, benzoylated with benzoyl chloride, and fractionated by HPLC as described above. One-ml fractions eluted from HPLC were collected in scintillation vials. Ten $\mathrm{ml}$ of Aquazol-2 was added to each vial and the radioactivity was measured with a liquid scintillation counter. Specific incorporation of ${ }^{14} \mathrm{C}$ activity into polyamines was defined as dpm per one nmol of polyamines per $24 \mathrm{hr}$.

Extraction and high performance liquid chromatographic analysis of $S$-methyladenosylhomocysteamine. S-Methyladenosylhomocysteamine (decarboxylated $S$-adenosylmethionine, dSAM) were measured by a method modified from that of Greenberg and Cohen. ${ }^{15)}$ Calli $(1.0 \mathrm{~g})$ were homogenized and centrifuged by the same method described in polyamine extractions. The supernatants were combined, the $\mathrm{pH}$ was adjusted to about 3 with potassium hydroxide, chilled on ice for $30 \mathrm{~min}$, and centrifuged to remove $\mathrm{KClO}_{4}$. Precipitates were washed with icecold $10 \mathrm{~mm}$ hydrochloric acid by centrifugation, and supernatants were combined and put on a column of SPSephadex $25(1 \times 5 \mathrm{~cm})$. The column was prepared in $10 \mathrm{~mm}$ hydrochloric acid. After washing with $35 \mathrm{ml}$ of $50 \mathrm{~mm}$ hydrochloric acid, dSAM was eluted with $40 \mathrm{ml}$ of $500 \mathrm{~mm}$ hydrochloric acid. The eluate was dried in vacuo at $32^{\circ} \mathrm{C}$ and the residue was dissolved in $100 \mu$ of $10 \mathrm{~mm}$ hydrochloric acid, and $20 \mu$ of the solution was used for HPLC.

HPLC of dSAM was run by the method described in the polyamine assay. Gradient elution with mobile phase A (131 ml of $0.1 \mathrm{M} \mathrm{NaH}_{2} \mathrm{PO}_{4}(\mathrm{pH} 2.50)$ containing $8 \mathrm{~mm} 1$ heptanesulfonic acid and $0.1 \mathrm{~mm} \mathrm{Na} \mathrm{N}_{2}$ EDTA and $1 \mathrm{ml}$ of acetonitrile) and mobile phase $\mathrm{B}\left(70 \mathrm{ml}\right.$ of $0.2 \mathrm{M} \mathrm{NaH} \mathrm{NO}_{4}$ (pH 3.10) containing $8 \mathrm{~mm}$ 1-heptanesulfonic acid and $30 \mathrm{ml}$ of acetonitrile) were used. A linear gradient starting from $20 \%$ mobile phase $B$ in mobile phase $A$, and ending 
with $60 \%$ B over a period of $20 \mathrm{~min}$ at a flow rate of $3 \mathrm{ml}$ per min.

Preparation and assay of enzyme. For preparation of SAMDCase, a callus was homogenized in a glass homogenizer with $1 \mathrm{ml}$ of $10 \mathrm{~mm}$ sodium phosphate buffer $(\mathrm{pH} 7.5)$ containing $0.1 \mathrm{~mm}$ dithiothreitol and $1 \mathrm{~mm}$ pyridoxal-5'phosphate at $4^{\circ} \mathrm{C}$. The homogenate was centrifuged at $12,000 \times g$ for $20 \mathrm{~min}$ at $0^{\circ} \mathrm{C}$. The supernatant fraction was used for the SAMDCase assay.

The SAMDCase was measured by a method modified from that of Montague et al. ${ }^{16)}$ The reaction was started by adding $100 \mu \mathrm{l}$ of the crude enzyme to $10 \mu \mathrm{l}$ of $\mathrm{L}-\left[{ }^{14} \mathrm{C}\right.$ carboxyl]-S-adenosylmethionine and $10 \mu \mathrm{l}$ of $5 \mathrm{~mm}$ pyridoxal-5'-phosphate. The reaction mixture was placed in a Warburg flask. A 7-mm diameter filter paper disc (Whatman No. 1) impregnated with $100 \mu \mathrm{l}$ of $2 \mathrm{~N}$ potassium hydroxide was used to trap the ${ }^{14} \mathrm{CO}_{2}$ liberated. After incubation at $37^{\circ} \mathrm{C}$ for $60 \mathrm{~min}$, the reaction was stopped with $0.5 \mathrm{ml}$ of $1 \mathrm{~N}$ sulfuric acid, and incubated for an additional $60 \mathrm{~min}$. The paper dises were taken out, dried, and placed in vials containing $1 \mathrm{ml}$ of distilled water and $10 \mathrm{ml}$ of Aquazol-2. ${ }^{14} \mathrm{C}$ activity was measured with a scintillation counter. The enzyme activity is expressed as ${ }^{14} \mathrm{CO}_{2}$ nmol per $\mathrm{mg}$ of protein per hour.

For the preparation of spermidine synthase and spermine synthase, a callus was homogenized in a glass homogenizer with $1 \mathrm{ml}$ of $1 \mathrm{M}$ triethanolamine sulfate buffer $(\mathrm{pH} 8.2)$ at $4^{\circ} \mathrm{C}$. The homogenate was centrifuged $12,000 \times g$ for $20 \mathrm{~min}$ at $0^{\circ} \mathrm{C}$. The supernatant fraction was used for the assay of spermidine synthase and spermine synthase.

The spermidine synthase was measured by the method of Cohen et al. $\left.{ }^{6}\right)$ The reaction was started by adding $250 \mu \mathrm{l}$ of the crude enzyme to $250 \mu \mathrm{l}$ of $0.5 \mathrm{M}$ triethanolamine sulfate buffer ( $\mathrm{pH} 8.2$ ) containing $25 \mu \mathrm{M}$ dSAM and $10 \mu \mathrm{l}$ of $\left[1,4-{ }^{14} \mathrm{C}\right]$ putrescine $(1 \mu \mathrm{Ci})$. After incubation at $37^{\circ} \mathrm{C}$ for $1 \mathrm{hr}$, the reaction was stopped by adding $1 \mathrm{ml}$ of $5 \%$ perchloric acid, and centrifuged at $1,500 \times \mathrm{g}$ for $5 \mathrm{~min}$. After adding $30 \mathrm{nmol}$ of spermidine to one $\mathrm{ml}$ of the supernatant, the $\left[{ }^{14} \mathrm{C}\right]$ spermidine produced was benzoylated with benzoyl chloride and fractionated by HPLC as described above. One-ml fractions eluted from HPLC were collected in scintillation vials. Ten $\mathrm{ml}$ of Aquazol-2 was added to each vial and the radioactivity was measured by a liquid scintillation counter. The enzyme activity is expressed as dpm of ${ }^{14} \mathrm{C}$ per $\mathrm{mg}$ of protein per hour.

Spermine synthase was measured by the method described for the assay of spermidine synthase except [diaminobutane $1,4-{ }^{14} \mathrm{C}$ ]spermidine was used in place of $\left[{ }^{14} \mathrm{C}\right]$ putrescine.

Enzyme protein was measured by the method of Lowry et al. ${ }^{17)}$

\section{Results}

Changes in the content of $\triangle S A M$ and the incorporation of $\left[1,4-{ }^{14} \mathrm{C}\right]$ putrescine or [diaminobutane $\left.1,4 .{ }^{14} \mathrm{C}\right]$ spermidine into spermine and/or spermine in Hiproly barley callus after auxin withdrawal

In Hiproly barley callus after auxin withdrawal, the change in the incorporation of $\left[1,4-{ }^{14} \mathrm{C}\right]$ putrescine into polyamines is shown in Fig. 1. When 2,4-D was removed from the callus, specific incorporation of ${ }^{14} \mathrm{C}$ into spermidine in the callus increased greatly, while ${ }^{14} \mathrm{C}$ activity of spermine increased gently.

Figure 2 shows changes in the incorporation of [diaminobutane $1,4-{ }^{14} \mathrm{C}$ ] spermidine into spermine in the callus after auxin withdrawal. The specific incorporation of ${ }^{14} \mathrm{C}$ into spermine increased gently. And the content of dSAM increased gently in the callus after auxin withdrawal (Fig. 2).

Hiproly barley callus placed on Murashige and Skoog's medium without 2,4-D formed

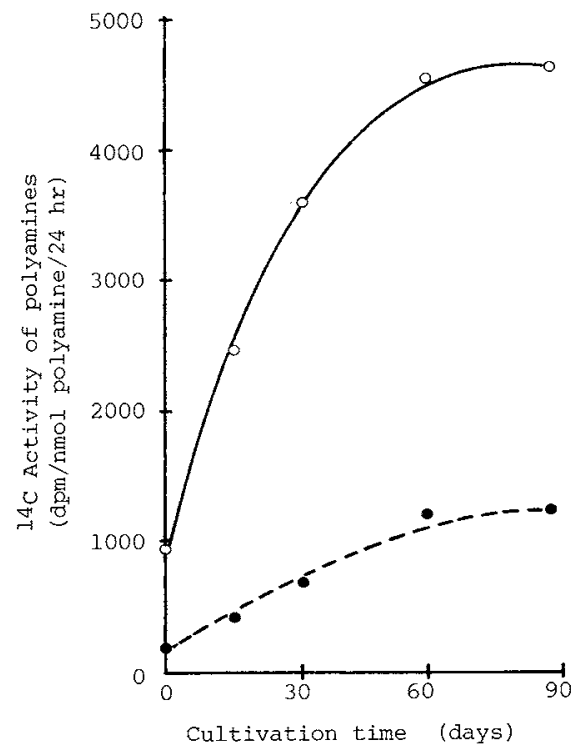

Fig. 1. Incorporation of $\left[1,4-{ }^{14} \mathrm{C}\right]$ Putrescine into Spermidine and Spermine in Hiproly Barley Callus after Auxin Withdrawal.

Calli at various stages were incubated for $24 \mathrm{hr}$ in the presence of $\left[1,4-{ }^{14} \mathrm{C}\right]$ putrescine $(0.5 \mu \mathrm{Ci})$, and ${ }^{14} \mathrm{C}$ activities of polyamines were measured. $\mathrm{O}-\mathrm{O}$, spermidine; - spermine. 


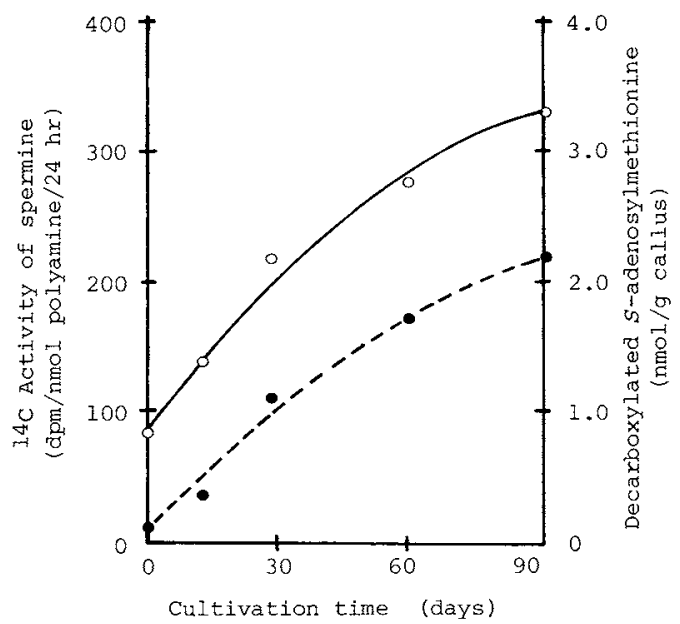

Fig. 2. Incorporation of [Diaminobutane $\left.1,4-{ }^{14} \mathrm{C}\right] \mathrm{Sper}$ midine into Spermine and Change in the Content of Decarboxylated $S$-Adenosylmethionine (dSAM) in Hiproly Barley Callus after Auxin Withdrawal.

Calli at various stages were incubated for $24 \mathrm{hr}$ in the presence of [diaminobutane $1,4-{ }^{14} \mathrm{C}$ ]spermidine $(0.5 \mu \mathrm{Ci})$, and ${ }^{14} \mathrm{C}$ activity of spermine was measured. $\mathrm{O}-\mathrm{O}$, spermine;

, dSAM.

adventitious roots by the 30 th day of cultivation. Specific incorporation of $[1,4-$ ${ }^{14} \mathrm{C}$ ]putrescine or [diaminobutane $1,4-{ }^{14} \mathrm{C}$ spermidine into spermidine and/or spermine increased, along with development of root formation. The dSAM production also increased in the callus with root formation.

Effects of DCHA on changes in the levels of polyamines in Hiproly barley callus

This experiment was designed to observe the effects of DCHA on changes in the levels of polyamines in Hiproly barley callus after 2,4D withdrawal.

Figure 3 indicates a strong inhibition of the spermidine synthesis at $10 \mathrm{~mm}$ DCHA. On the 30 th day after cultivation, levels of spermidine were reduced to about $30 \%$ of the control. On the other hand, spermine synthesis was greatly enhanced by DCHA. Levels of spermine in the callus increased about 2-fold after treatment with $10 \mathrm{~mm}$ DCHA, as compared with the control, on the 30 th day after cultivation.

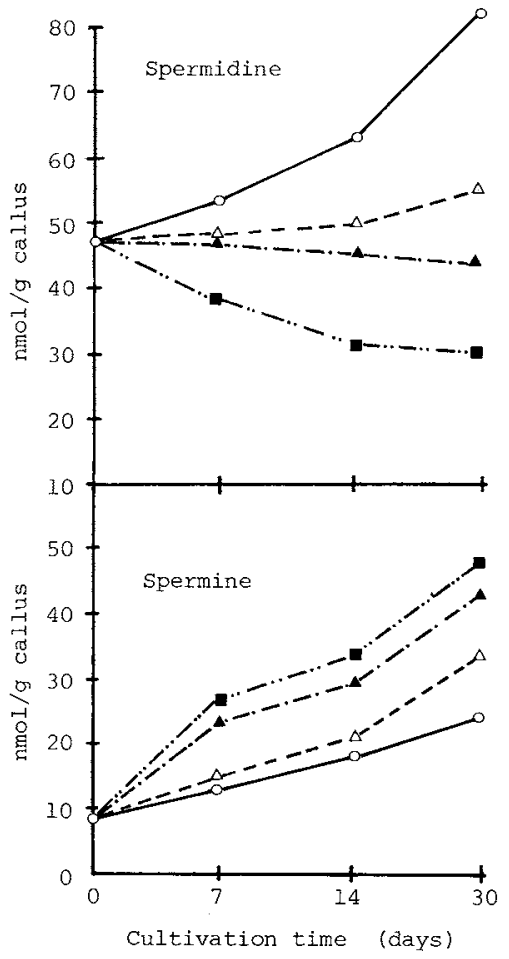

Fig. 3. Effects of Dicyclohexylamine (DCHA) on Spermidine and Spermine Levels of Hiproly Barley Callus. $\bigcirc-\mathrm{O}$, control; $\triangle-\triangle, 1 \mathrm{~mm}$ DCHA; $\boldsymbol{\Delta}-\mathbf{\Lambda}, 5 \mathrm{~mm}$ DCHA; - $\square, 10 \mathrm{~mm}$ DCHA.

Effects of DCHA on the incorporation of $\mathrm{L}-[3,4-$ ${ }^{14} \mathrm{Clmethionine} \mathrm{into} \mathrm{spermidine} \mathrm{and} \mathrm{spermine}$

The effects of DCHA on the incorporation of $\mathrm{L}-\left[3,4-{ }^{14} \mathrm{C}\right]$ methionine into polyamines in the callus are shown in Table I. The rates of the incorporation of $\mathrm{L}-\left[3,4-{ }^{14} \mathrm{C}\right]$ methionine into spermine increased greatly when the callus was transferred to the medium containing DCHA. On the 30 th day after cultivation, specific incorporation of ${ }^{14} \mathrm{C}$ activity into spermine had increased about 6 -fold in the presence of $10 \mathrm{~mm}$ DCHA, compared with the control, but DCHA strongly inhibited the incorporation of $\mathrm{L}-\left[3,4-{ }^{14} \mathrm{C}\right]$ methionine into spermidine. On the 30 th day after cultivation specific incorporation of ${ }^{14} \mathrm{C}$ activity into spermidine in the callus treated with $10 \mathrm{~mm}$ DCHA had decreased to about $14 \%$ of the control. 
Table I. EfFects of DicycloheXylamine (DCHA) ON THE INCORPORATION OF L-[3,4- $\left.{ }^{14} \mathrm{C}\right]$ METHIONINE into SPERmidine (Spd) AND SPERmine (Spm) of Hiproly Barley Callus

\begin{tabular}{|c|c|c|c|c|c|}
\hline \multirow{3}{*}{ Chemical } & \multirow{3}{*}{$\begin{array}{c}\text { Concentration } \\
\text { (mM) }\end{array}$} & \multicolumn{4}{|c|}{${ }^{14} \mathrm{C}$ Activity } \\
\hline & & \multicolumn{2}{|c|}{ 14th day } & \multicolumn{2}{|c|}{30 th day } \\
\hline & & $\begin{array}{l}\text { Spd } \\
(\mathrm{dpm}\end{array}$ & $\begin{array}{r}\text { Spm } \\
/ \mathrm{nmol}\end{array}$ & $\begin{array}{l}\text { Spd } \\
\text { amine }\end{array}$ & $\begin{array}{r}\text { Spm } \\
24 \mathrm{hr})\end{array}$ \\
\hline Control & - & 57.8 & 30.0 & 79.3 & 32.1 \\
\hline \multirow[t]{3}{*}{ DCHA } & 1.0 & 36.5 & 52.8 & 16.4 & 69.9 \\
\hline & 5.0 & 24.0 & 67.0 & 15.8 & 74.0 \\
\hline & 10.0 & 19.3 & 110.1 & 11.0 & 176.8 \\
\hline
\end{tabular}

Calli were incubated for $24 \mathrm{hr}$ in the presence of the indicated concentration of DCHA and $\mathrm{L}-\left[3,4-{ }^{14} \mathrm{C}\right]-$ methionine $(1.0 \mu \mathrm{Ci})$, and ${ }^{14} \mathrm{C}$ activities of spermidine and spermine were measured.

Table II. EFFects of Dicyclohexylamine (DCHA) ON THE INCOR PORATION OF $\left[1,4-{ }^{14} \mathrm{C}\right]$ PUTRESCINE INTO Spermidine (Spd) and the ACtivity of Spermidine Synthase in Hiproly Barley Callus

\begin{tabular}{|c|c|c|}
\hline Sample & $\begin{array}{c}{ }^{14} \mathrm{C} \text { Activity } \\
(\mathrm{dpm} / \mathrm{nmol} \\
\mathrm{spd} / 24 \mathrm{hr})\end{array}$ & $\begin{array}{c}\text { Spd synthase } \\
(\mathrm{dpm} / \mathrm{mg} \\
\text { protein } / \mathrm{hr})\end{array}$ \\
\hline \multicolumn{3}{|l|}{ 14th day } \\
\hline Control & 2349.0 & 166.5 \\
\hline $1.0 \mathrm{~mm}$ DCHA & 1352.5 & 138.5 \\
\hline $5.0 \mathrm{mM}$ ГСНН & 962.5 & 108.5 \\
\hline $10.0 \mathrm{~mm}$ DCHA & 959.0 & 103.5 \\
\hline \multicolumn{3}{|l|}{ 30th day } \\
\hline Control & 3580.5 & 325.9 \\
\hline $1.0 \mathrm{~mm}$ DCHA & 596.6 & 111.0 \\
\hline $5.0 \mathrm{~mm}$ DCHA & 581.3 & 102.8 \\
\hline $10.0 \mathrm{~mm}$ DCHA & 512.5 & 94.7 \\
\hline
\end{tabular}

Calli were incubated for $24 \mathrm{hr}$ in the presence of the indicated concentration of DCHA and $\left[1,4-{ }^{14} \mathrm{C}\right]$ putrescine $(0.5 \mu \mathrm{Ci})$ and ${ }^{14} \mathrm{C}$ activity of spermidine was measured. Enzyme activity was measured as described in Materials and Methods.

Effects of DCHA on the incorporation of [1,4$\left.{ }^{14} \mathrm{C}\right]$ putrescine into spermidine and the activity of spermidine synthase

The rates of the incorporation of $[1,4$ ${ }^{14} \mathrm{C}$ ]putrescine into spermidine were decreased greatly by the addition of DCHA. On the 14th and 30 th day after cultivation, specific incorporation of ${ }^{14} \mathrm{C}$ activity into spermidine
Table III. EFFECTS OF DiCYCLOHEXYLAMINE (DCHA) ON THE INCORPORATION OF [DIAMINOBUTANE $1,4-{ }^{14} \mathrm{C}$ SPERmidine into Spermine (Spm) and the ACTIVITy OF SPERMINE SyNTHASE IN Hiproly Barley Callus

\begin{tabular}{ccc}
\hline Sample & $\begin{array}{c}{ }^{14} \text { C Activity } \\
(\mathrm{dpm} / \mathrm{nmol} \\
\text { spm/24 hr) }\end{array}$ & $\begin{array}{c}\text { Spm synthase } \\
(\mathrm{dpm} / \mathrm{mg} \\
\text { protein } / \mathrm{hr})\end{array}$ \\
\hline 14th day & & \\
Control & 134.4 & 23.3 \\
1.0 mm DCHA & 1120.0 & 60.8 \\
$5.0 \mathrm{~mm}$ DCHA & 3353.1 & 138.0 \\
10.0 mm DCHA & 4053.9 & 156.8 \\
30 th day & & \\
Control & 217.0 & 31.0 \\
1.0 mm DCHA & 3530.5 & 120.0 \\
$5.0 \mathrm{~mm}$ DCHA & 4147.5 & 140.5 \\
10.0 mm DCHA & 4837.8 & 394.5 \\
\hline
\end{tabular}

Calli were incubated for $24 \mathrm{hr}$ in the presence of the indicated concentration of DCHA and [diaminobutane $\left.1,4-{ }^{14} \mathrm{C}\right]$ spermidine $(0.5 \mu \mathrm{Ci})$ and ${ }^{14} \mathrm{C}$ activity of spermidine was measured. Enzyme activity was measured as described in Materials and Methods.

was reduced about 66 and $86 \%$, respectively, by $10 \mathrm{~mm}$ DCHA as compared with the control (Table II).

The activity of spermidine synthase in the callus was inhibited by treatment of DCHA. Compared with the control, the activity of spermidine synthase was reduced by $10 \mathrm{~mm}$ DCHA to about 65 and $30 \%$ respectively, on the 14 th and 30 th day after cultivation (Table II).

Effects of DCHA on the incorporation of [diaminobutane $\left.1,4-{ }^{14} \mathrm{C}\right]$ spermidine into spermine and the activity of spermine synthase

DCHA stimulated spermine biosynthesis. On the 14 th and 30 th day after cultivation, specific incorporation of ${ }^{14} \mathrm{C}$ activity into spermine was increased about 30 and 20-fold, respectively, by $10 \mathrm{~mm}$ DCHA, as compared with the control (Table III). The results in Table III show that the activity of spermine synthase in the callus treated with $10 \mathrm{~mm}$ DCHA increase by about 7 and 13-fold, respectively, of the control on the 14th and 30th day after cultivation. 
Table IV. Effects of Dicyclohexylamine (DCHA) on the Decarboxylated $S$-Adenosylmethionine (dSAM) AND THE ACTIVITY OF S-ADENOSYLMETHIONINE DECARBOXYLASE (SAMDCase) in Hiproly Barley Callus

\begin{tabular}{ccc}
\hline Sample & $\begin{array}{c}\text { dSAM } \\
\text { (nmol/g } \\
\text { callus) }\end{array}$ & $\begin{array}{c}\text { SAMDCase } \\
\text { activity } \\
\left({ }^{14} \mathrm{CO}_{2} \mathrm{nmol} / \mathrm{mg}\right. \\
\text { protein } / \mathrm{hr})\end{array}$ \\
\hline 14th day & & \\
Control & 0.29 & 9.5 \\
$1.0 \mathrm{~mm}$ DCHA & 1.13 & 17.3 \\
$5.0 \mathrm{~mm}$ DCHA & 4.01 & 18.8 \\
$10.0 \mathrm{~mm}$ DCHA & 5.20 & 24.3 \\
30 th day & & \\
Control & 1.08 & 21.6 \\
$1.0 \mathrm{~mm}$ DCHA & 9.61 & 35.9 \\
$5.0 \mathrm{~mm}$ DCHA & 12.22 & 39.7 \\
10.0 mM DCHA & 23.71 & 43.8 \\
\hline
\end{tabular}

$\mathrm{dSAM}$ and SAMDCase activity were measured as described in Materials and Methods.

Effects of DCHA on the content of $d S A M$ and the activity of $S A M D C$ ase in Hiproly barley callus

Table IV shows the effects of DCHA on the activity of SAMDCase, which is the ratelimiting enzyme in the pathway of polyamine biosynthesis. DCHA had a significant effect on the activity of SAMDCase. The activity of SAMDCase was increased up to 2-fold by $10 \mathrm{~mm}$ DCHA as compared with the controls after cultivation.

Moreover, the contents of $\mathrm{dSAM}$ in the callus were greatly increased by the addition of DCHA. As compared with the control, the contents of dSAM were increased about 18 and 22 -fold, respectively, by $10 \mathrm{~mm}$ DCHA on the 14 th and 30 th day after cultivation.

\section{Discussion}

A decrease in spermidine contents induced by DCHA was already confirmed in pine cotyledons ${ }^{10}$ and germinating seeds of Acer. ${ }^{11}$ Sindhu and Cohen ${ }^{18)}$ have recently reported that DCHA was a specific inhibitor of Chinese cabbage spermidine synthase. DCHA effectively inhibits the synthesis of spermidine.
DCHA may be useful in studies of the regulatory mechanisms of biosynthesis of spermidine and spermine.

In Hiproly barley callus after auxin withdrawal, the rates of incorporation of $[1,4-$ ${ }^{14} \mathrm{C}$ ]putrescine or [diaminobutane $1,4-{ }^{14} \mathrm{C}$ ]spermidine into spermidine and/or spermine were increased gradually. However, the addition of DCHA suppressed the incorporation of $\left[{ }^{14} \mathrm{C}\right]$ putrescine into spermidine and stimulated the incorporation of [diaminobutane $\left.1,4-{ }^{14} \mathrm{C}\right]$ spermidine into spermine. Specific incorporation of ${ }^{14} \mathrm{C}$-spermidine into spermine was increased up to 20 -fold, and the spermine contents in the callus treated with DCHA increased about 2-fold, compared with that of the control. Our results demonstrate that DCHA inhibition induced a shift from synthesis of spermidine to that of spermine.

In the presence of DCHA, the activity of spermine synthase in Hiproly barley callus was greatly elevated. dSAM serves as a source of an aminopropyl moiety for the biosynthesis of spermidine and spermine. ${ }^{6)}$ The activity of spermine synthase will be closely related to the levels of dSAM. Elevated levels of dSAM have been thought to stimulate the spermine biosynthesis in Hiproly barley callus after auxin withdrawal.

Athman-Hongisto ${ }^{19)}$ reported that SAMDCase was strongly inhibited by spermidine, and that inhibition of spermidine biosynthesis induced an increase in the SAMDCase activity. Spermidine functions as an effective repressor of SAMDCase. On Hiproly barley callus, the addition of DCHA also leads to increases in the activity of SAMDCase.

During inhibition of spermidine synthase in Hiproly barley callus by DCHA, the incorporation of $\mathrm{L}-\left[3,4-{ }^{14} \mathrm{C}\right]$ methionine into spermine increased about 6-fold, and the activity of SAMDCase was increased up to 2-fold, compared with the control. Moreover, our results show that the levels of dSAM were increased about 20 -fold by the treatment with DCHA. These findings ovbiously indicate that increases in available size of dSAM pool appeared to increase the synthesis of spermine. 
Thus, upon inhibition of biosynthesis of spermidine, the increase in dSAM levels occurs rapidly, and in turn, results in an increased synthesis of spermine. The availability of dSAM may be rate-limiting for the synthesis of spermine in the callus of Hiproly barley after auxin withdrawal.

\section{References}

1) N. Bagni, D. Serafini-Fracassini and P. Torrigiani, "Plant Growth Substances," ed. by P. E. Wareing, Academic Press, London, 1982, p. 473.

2) R. D. Slocum, R. Kaur-Sawhney and A. W. Galston, Arch. Biochem. Biophys., 235, 283 (1984).

3) T. A. Smith, Ann. Rev. Plant Physiol., 36, 117 (1985).

4) A. W. Galston, BioScience, 33, 382 (1983).

5) Y. Katoh, T. Hasegawa, T. Suzuki and T. Fujii, Agric. Biol. Chem., 49, 1027 (1985).

6) S. S. Cohen, R. Balint and P. K. Sindhu, Plant Physiol., 68, 1150 (1981).

7) A. J. Bitonti, P. P. McCann and A. Sjoerdsma, Biochem. J., 208, 435 (1982).
8) B. G. Feuersten, D. F. Deen and L. J. Marton, Cancer Res., 45, 4950 (1985).

9) J. L. A. Mitchell, D. W. Maham, P. P. McCann and P. Qasba, Biochim. Biophys. Acta, 840, 309 (1985).

10) S. Biondi, N. Bagni and A. Sansovini, Physiol. Plant., 66, 41 (1986).

11) M. A. Walker, D. R. Roberts, L. Y. Shih and E. B. Bumbroff, Plant Cell Physiol., 26, 967 (1985).

12) P. Barbieri, P. Torrigiani and N. Bagni, Giorn. Bot. Ital., 117, 61 (1983).

13) A. A. Fienberg, J. H. Chot, W. P. Lubich and Z. R. Sung, Planta, 162, 532 (1984).

14) J. W. Redmond and A. Tseng, J. Chromatogr., 170, 479 (1979).

15) M. L. Greenberg and S. S. Cohen, Plant Physiol., 78, 568 (1985).

16) M. J. Montague, J. W. Koppenbrink and F. G. Jaworki, Plant Physiol., 62, 430 (1978).

17) O. H. Lowry, N. J. Rosebrough, A. L. Farr and R. J. Randall, J. Biol. Chem., 193, 265 (1951).

18) R. K. Sindhu and S. S. Cohen, Plant Physiol., 74, 645 (1984).

19) L. Athman-Hongidto, Biochem. $J ., 190,747$ (1980). 